\title{
CLOTHING OF INFANTS IN SUMMER AND WINTER*
}

\author{
L. W. SAUER, M.D. \\ CHICAGO
}

McClure and Sauer ${ }^{1}$ emphasized the fact that in the study of the relation of summer heat to infant mortality the heat regulatory power of the infant has not received its due consideration. It is evident that a number of factors are at work to maintain a proper heat balance; on the one side such as influence the heat production, on the other such as determine its elimination. We are indebted to Rubner ${ }^{2}$ and his co-workers for the most important data about the influence of clothing on heat loss. At moderate room temperature a certain amount of clothing reduced the heat loss by conduction and radiation to onethird of the loss through the bare skin. With a temperature of $37 \mathrm{C}$. the interference with the heat loss may be so great as to cause serious disturbances. This is in the adult who has at his disposal the potent heat regulation of visible perspiration. The infant, with its relatively greater body surface, is usually devoid of most of this regulatory mechanism up to a certain age. Excluding a few minor means of heat dissipation, the heat loss is dependent here on the evaporation of water from the lungs, the so-called insensible perspiration, and conduction and radiation. It is an open question to what degree the evaporation of water from the lungs of the infant can participate in the elimination of heat. The results of McClure and Sauer indicate that the insensible perspiration is of great importance, particularly with high room temperature. Conduction and radiation cannot function without a difference between the surface temperature and that of the surrounding air. With usual hospital clothing the heat loss from the covered areas by these means is very markedly reduced at a room temperature of $31 \mathrm{C}^{1}$ In this connection an influence of clothing on the heat loss is evident. The relative importance of the various factors entering in consideration under various conditions has not been determined with any degree of accuracy. Nevertheless, it is clearly of importance to gain as much information as possible about any one factor exercising an influence on any of the mechanisms of heat loss. Very few data are available with reference to clothing, although

* From the Otho S. A. Sprague Memorial Institute Laboratory of the Children's Memorial Hospital.

1. McClure and Sauer: Am. J. Dis. Child. 9:490, 1915; Am. J. Dis. Child. 10 : 425, 1915; Arch. Int. Med. 21:428, 1918.

2. Rubner: Lehrb. d. Hygiene, 1907, Ed. 8. 
it is recognized that the interference of clothing with heat loss may be a factor in the morbidity of the infant from gastro-intestinal disorders.

I determined the weight of the clothing of 400 infants from 1 week to 2 years of age. The infants were brought to the infant welfare stations, and they represent the tenement population. It was their first visit to the station. In 200 cases, hot days of the summers of 1914, 1915 and 1916 were chosen ; and in 200, cold days of the winters of 1914, 1915 and 116. None of the mothers had received any instructions about clothing their infants. Only the clothing worn regularly indoors was weighed. The fabric of which the clothes were made was almost without exception cotton. It is impossible to discuss the importance of various kinds of clothes and fabrics in the case of

TABLE 1.-Results of Weighing Infants in Summer and in Winter

\begin{tabular}{|c|c|c|c|c|c|c|c|c|c|}
\hline Group & Series & Name & $\begin{array}{c}1 \\
\\
\text { Age } \\
\text { in } \\
\text { Mos. }\end{array}$ & $\begin{array}{c}2 \\
\text { Feeding }\end{array}$ & $\begin{array}{c}3 \\
\text { Body } \\
\text { Weight } \\
\text { in Gm. }\end{array}$ & $\begin{array}{c}4 \\
4 \\
\text { Indoor } \\
\text { Cloth- } \\
\text { ing } \\
\text { Weight } \\
\text { in Gm. }\end{array}$ & $\begin{array}{c}5 \\
\text { Per } \\
\text { Cent. } \\
\text { of } \\
\text { Oloth- } \\
\text { ing to } \\
\text { Body } \\
\text { Weight }\end{array}$ & $\begin{array}{c}6 \\
\text { Out- } \\
\text { door } \\
\text { Temp- } \\
\text { era- } \\
\text { ture, } \\
\text { F. }\end{array}$ & Remarks \\
\hline \multirow{2}{*}{ I } & Summer & $\begin{array}{l}\text { G. } \\
\text { k. } \\
\text { K. }\end{array}$ & $\begin{array}{l}1 \\
21 / 2 \\
2 \% 3\end{array}$ & $\begin{array}{l}\text { Breast } \\
\text { Breast } \\
\text { Bottle }\end{array}$ & $\begin{array}{l}3,636 \\
4,772 \\
4,318 \\
\end{array}$ & $\begin{array}{l}460 \\
530 \\
500\end{array}$ & $\begin{array}{l}12.7 \\
11.1 \\
11.3 \\
\end{array}$ & $\begin{array}{l}92 \\
92 \\
92\end{array}$ & $\begin{array}{l}\text { Ileocolitis, toxic } \\
\text { Diarrhea, } \\
\text { Blood in stools }\end{array}$ \\
\hline & Winter & $\begin{array}{l}\text { Z. } \\
\text { F. } \\
\text { B. }\end{array}$ & $\begin{array}{l}1 \\
11 / 2 \\
11 / 2\end{array}$ & $\begin{array}{l}\text { Bottle } \\
\text { Bottle } \\
\text { Bottle }\end{array}$ & $\begin{array}{l}4,160 \\
3,380 \\
2,590\end{array}$ & $\begin{array}{l}200 \\
230 \\
400\end{array}$ & $\begin{array}{r}4.8 \\
6.8 \\
15.0\end{array}$ & $\begin{array}{l}26 \\
26 \\
26\end{array}$ & $\begin{array}{l}\text { Well } \\
\text { Well } \\
\text { Well }\end{array}$ \\
\hline \multirow{2}{*}{ II } & Summer & $\begin{array}{l}\text { J. } \\
\text { G. } \\
\text { H. }\end{array}$ & $\begin{array}{l}6 \\
4 \\
7\end{array}$ & $\begin{array}{l}\text { Breast } \\
\text { Bottle } \\
\text { Bottle }\end{array}$ & $\begin{array}{l}7,010 \\
5,530 \\
7,550\end{array}$ & $\begin{array}{r}270 \\
1,090 \\
289\end{array}$ & $\begin{array}{r}3.8 \\
19.0 \\
4.0\end{array}$ & $\begin{array}{l}85 \\
85 \\
85\end{array}$ & $\begin{array}{l}\text { Well } \\
\text { Well } \\
\text { Well }\end{array}$ \\
\hline & Winter & $\begin{array}{l}\text { S. } \\
\text { L. } \\
\text { M. }\end{array}$ & $\begin{array}{l}7 \\
5 \\
8\end{array}$ & $\begin{array}{l}\text { Bottle } \\
\text { Bottle } \\
\text { Breast }\end{array}$ & $\begin{array}{l}6,480 \\
7,750 \\
7,100\end{array}$ & $\begin{array}{r}1,000 \\
700 \\
460\end{array}$ & $\begin{array}{r}15.4 \\
9.0 \\
6.5\end{array}$ & $\begin{array}{l}28 \\
28 \\
28\end{array}$ & $\begin{array}{l}\text { Well } \\
\text { Well } \\
\text { Slight cold }\end{array}$ \\
\hline \multirow{2}{*}{ III } & Summer & $\begin{array}{l}\text { G. } \\
\text { C. }\end{array}$ & $\begin{array}{l}14 \\
11 \\
15\end{array}$ & $\begin{array}{l}\text { Bottle } \\
\text { Bottle } \\
\text { Bottle }\end{array}$ & $\begin{array}{l}8,863 \\
8,800 \\
9,000\end{array}$ & $\begin{array}{l}400 \\
120 \\
400\end{array}$ & $\begin{array}{l}4.5 \\
1.3 \\
4.4\end{array}$ & $\begin{array}{l}85 \\
85 \\
85\end{array}$ & $\begin{array}{l}\text { Well } \\
\text { Well } \\
\text { Well }\end{array}$ \\
\hline & Winter & $\begin{array}{l}\text { Q. } \\
\text { C. }\end{array}$ & $\begin{array}{l}18 \\
10 \\
12\end{array}$ & $\begin{array}{l}\text { Bottle } \\
\text { Breast } \\
\text { Bottle }\end{array}$ & $\begin{array}{r}11,150 \\
8,050 \\
9,450\end{array}$ & $\begin{array}{l}400 \\
300 \\
320\end{array}$ & $\begin{array}{l}3.7 \\
3.7 \\
3.4\end{array}$ & $\begin{array}{l}22 \\
22 \\
22\end{array}$ & $\begin{array}{l}\text { Well } \\
\text { Cough } \\
\text { Well }\end{array}$ \\
\hline
\end{tabular}

infants because no accurate data are available. The material used for the clothing of our infants and the way it was put on was rather uniform. For these reasons the weighing of the clothing is the most convenient method of obtaining comparable data. The question whether there are marked differences in the amount of indoor clothing worn by babies in summer and winter is of interest in itself. The further purpose was to see whether a relationship could be established between excessive clothing and gastro-intestinal disorders. The latter phase of the subject had to be abandoned for the obvious reason that when it seemed necessary the mothers were immediately instructed to modify the clothing. Very few of the infants came to the stations 
with sickness such as diarrhea, etc. The number of observations is much too small to be utilized for this latter purpose. The infants were not selected, and only in a few cases had extra clothing been put on the child on account of sickness. By far the greater majority of the infants were not hospital or dispensary cases.

The tabulation of each of the 400 cases would be rather superfluous. They were divided into three groups according to weight: Group I comprises infants weighing up to $5 \mathrm{~kg}$.; Group II infants weighing from 5 to $8 \mathrm{~kg}$. (both inclusive); and Group III infants weighing more than $8 \mathrm{~kg}$. Table 1 gives a few examples of each group. In the fifth column the amount of clothing in grams is given per $100 \mathrm{gm}$. of body weight. In this way results can be compared with greater ease. It might perhaps be better to determine the clothing with reference to the body surface, at the same time taking in consideration the relation of the clothed surface to the surface left

TABLE 2.-Summary of Results in Maximum and Minimum Values

\begin{tabular}{|c|c|c|c|c|c|c|c|c|}
\hline Group & $\begin{array}{c}1 \\
\begin{array}{c}\text { Number } \\
\text { of } \\
\text { Infants }\end{array}\end{array}$ & $\begin{array}{c}2 \\
\\
\text { Aver- } \\
\text { age } \\
\text { Body } \\
\text { Weight } \\
\text { in } \\
\text { Kg. }\end{array}$ & $\begin{array}{c}3 \\
\\
\text { Aver- } \\
\text { age } \\
\text { Cloth- } \\
\text { ing } \\
\text { Weight } \\
\text { in } \\
\text { Gm. }\end{array}$ & $\begin{array}{c}4 \\
\text { Per } \\
\text { Cent. of } \\
\text { Aver. } \\
\text { Cloth- } \\
\text { ing } \\
\text { Weight } \\
\text { to } \\
\text { Aver. } \\
\text { Body } \\
\text { Weight }\end{array}$ & $\begin{array}{l}\text { Maxi- } \\
\text { mum } \\
\text { Cloth- } \\
\text { ing } \\
\text { Weight } \\
\text { in } \\
\text { Gm. }\end{array}$ & $\begin{array}{c}6 \\
\text { Mini- } \\
\text { mum } \\
\text { Cloth- } \\
\text { ing } \\
\text { Weight } \\
\text { in } \\
\text { Gm. }\end{array}$ & $\begin{array}{c}\text { Maxi- } \\
\text { mum } \\
\text { per } \\
\text { Cent. }\end{array}$ & $\begin{array}{l}\text { Mini- } \\
\text { muni } \\
\text { per } \\
\text { Cent. }\end{array}$ \\
\hline $\begin{array}{l}\text { 1. Infants up to } 5 \mathrm{~kg} . \\
\text { Summer........... } \\
\text { Winter........... } \\
\text { II. Infants from } 5 \text { to }\end{array}$ & $\begin{array}{l}38 \\
63\end{array}$ & $\begin{array}{l}4.2 \\
4.0\end{array}$ & $\begin{array}{l}365 \\
362\end{array}$ & $\begin{array}{l}8.7 \\
9.1\end{array}$ & $\begin{array}{r}710 \\
1,050\end{array}$ & $\begin{array}{l}100 \\
170\end{array}$ & $\begin{array}{l}19.2 \\
37.5\end{array}$ & $\begin{array}{l}2.1 \\
5.2\end{array}$ \\
\hline 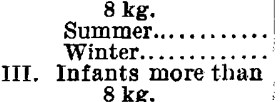 & $\begin{array}{r}105 \\
82\end{array}$ & $\begin{array}{l}6.5 \\
6.4\end{array}$ & $\begin{array}{l}353 \\
415\end{array}$ & $\begin{array}{l}5.4 \\
6.5\end{array}$ & $\begin{array}{l}1,090 \\
1,000\end{array}$ & $\begin{array}{l}100 \\
110\end{array}$ & $\begin{array}{l}19.7 \\
15.4\end{array}$ & $\begin{array}{l}1.5 \\
1.8\end{array}$ \\
\hline $\begin{array}{l}\text { Summer............... } \\
\text { Winter.................. }\end{array}$ & $\begin{array}{l}57 \\
55\end{array}$ & $\begin{array}{l}9.2 \\
9.5\end{array}$ & $\begin{array}{l}371 \\
463\end{array}$ & $\begin{array}{l}4.0 \\
4.9\end{array}$ & $\begin{array}{r}560 \\
1,500\end{array}$ & $\begin{array}{l}120 \\
280\end{array}$ & $\begin{array}{r}5.2 \\
15.2\end{array}$ & $\begin{array}{l}1.3 \\
\mathbf{2 . 6}\end{array}$ \\
\hline
\end{tabular}

uncovered. Columns 2,3 and 4 of Table 2 contain the summary of the results; columns 5, 6, 7 and 8 the individual maximum and minimum values. The first group includes infants up to three or four months. In this group the difference between the summer and winter clothing is practically nil, and the proportion of the weight of clothing to body weight is higher than in Groups II and III. No doubt the custom of dressing infants in long clothes, regardless of any other consideration but age, is responsible for this result. The difference in the weight of winter and summer clothing in the second group, comprising infants from about three to ten months of age, is $62 \mathrm{gm}$. The summer clothing weighs about 14.9 per cent. (about one-seventh) less than the winter clothing. The third group comprises the older infants, whose 
age rarely exceeded fifteen months. The summer clothing weighs $92 \mathrm{gm}$. less than the winter clothing, the difference being 19.9 per cent. (about one-fifth).

The difference between the body weights of the summer and winter infants has not been considered. In the first group the summer infants weigh about 5 per cent. more than the winter infants; in the second there is a difference of about 1.6 per cent. in favor of summer; and in the third the winter weights exceed the summer weights by about 3.2 per cent. In the absence of standards it is impossible to say whether the amount of clothing for winter or summer is approximately proper. The only figures available for comparison are those of Griffith. ${ }^{3}$ The nurse in charge of the hospital dispensary conducted the weighings which were obtained during autumn and winter. The figures given by him served for the calculations as given below.

TABLE 4.-Results of Weighings in Dispensary

\begin{tabular}{r|c|c|c|c}
\hline Age & Cases & $\begin{array}{c}\text { Average } \\
\text { Body Weight, } \\
\text { Kg. }\end{array}$ & $\begin{array}{c}\text { Average Weight } \\
\text { of Clothing, } \\
\text { Gm. }\end{array}$ & $\begin{array}{c}\text { Clothing per } \\
\text { Cent. of } \\
\text { Body Weight }\end{array}$ \\
\hline Up to 3 mos. & 10 & 2.69 & 850 & 31.6 \\
3 to 6 mos. & 19 & 4.14 & 82 & 19.9 \\
6 to 9 mos. & 13 & 5.53 & 850 & 15.4 \\
9 to 12 mos. & 10 & 6.04 & 822 & 12.6 \\
12 to 24 mos. & 21 & 7.45 & 964 & 12.9 \\
\hline
\end{tabular}

Griffith further determined the relation of this clothing to a mean gross weight of infants. This he obtained by the utilization of the statistics of various investigators. Calculated for the body weight (undressed) we get:

TABLE 4.-Relation of Clothing to Mean Gross Weight

\begin{tabular}{|c|c|c|c|c|}
\hline \multirow[b]{2}{*}{ Age } & \multicolumn{2}{|c|}{ Griffith } & \multicolumn{2}{|c|}{ Sauer } \\
\hline & $\begin{array}{l}\text { Weight } \\
\text { of } \\
\text { Infant }\end{array}$ & $\begin{array}{l}\text { Clothing per } \\
\text { Cent. of } \\
\text { Body Weight }\end{array}$ & $\begin{array}{l}\text { Weight } \\
\text { of } \\
\text { Infant }\end{array}$ & $\begin{array}{l}\text { Clothing per } \\
\text { Cent. of } \\
\text { Body Weight }\end{array}$ \\
\hline Up to $3 \mathrm{mos}$. & 4.5 & 18.9 & 4.0 & 9.1 \\
\hline 3 to $6 \mathrm{mos}$. & 6.5 & 12.6 & 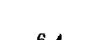 & s \\
\hline 6 to 9 mos. & 7.9 & 11.3 & 0.9 & 0.5 \\
\hline 9 to $12 \mathrm{mos}$. & 9.1 & 9.0 & 05 & 10 \\
\hline 12 to $24 \mathrm{mos}$ & 11.0 & 8.8 & 8.0 & 4.9 \\
\hline
\end{tabular}

Under Griffith the figures obtained from his data are given, under Sauer the figures of my winter series are adjoined. The relationship of clothing to the body weight of the babies of Griffith is rather high. The reason for this is evidently the poor state of nutrition of

3. Griffith: Trans. Am. Med. Assn., Section Dis. Child., p. 79, 1917. 
his material. However, when the weight of the clothing as determined by him is brought in relation with the body weight of normal infants, the amount of clothing is much higher than that of the corresponding group of our children. It is possible that his infants were overdressed because they were below par. As Griffith implies, the decision whether a baby is underdressed or overdressed is left to the experienced eye. This means that the decision depends on custom, leaving out of consideration the possible vagaries of the experienced eye itself.

The fact that so little work has been done and that our results differ so greatly seems to make it extremely desirable that some standards, based on experimentation, be established with reference to rational infants' clothing. This should include the various materials and fabrics. 